\title{
PERAN PENDIDIKAN, PELATIHAN BAHASA INGGRIS, DAN TEKNIK KEPEMANDUAN DALAM PENGEMBANGAN MINA WISATA
}

\author{
Ida Bagus Jelantik Swasta \\ FMIPA Universitas Pendidikan Ganesha \\ email: bagusjelantik@yahoo.com
}

\begin{abstract}
Abstrak: Tujuan penelitian ini adalah untuk mendeskripsikan peranan pendidikan dan pelatihan bahasa Inggris dan teknik kepemanduan dalam meningkatkan kemampuan karyawan CV Dewata Laut dalam melayani wisatawan yang berkunjung ke perusahaan itu. Metode yang digunakan adalah metode praeksperimental dengan perlakuan berupa pendidikan dan pelatihan bahasa Inggris dan teknik kepemanduan. Data dikumpulkan melalui teknik tes, observasi, wawancara, dan kuesioner. Tes yang dipakai adalah tes pemahaman dan tes keterampilan yang dilakukan sebelum kegiatan (pretes) dan setelah kegiatan (postes). Data dianalisis melalui teknik deskriptif kuantitatif dan kualitatif. Hasil yang diperoleh dalam penelitian ini adalah (1) kemampuan berbahasa Inggris para karyawan CV. Dewata Laut meningkat sebanyak 53,69 persen; (2) kemampuan teknik kepemanduan meningkat sebanyak 49,53 persen; dan (3) kemampuan melayani wisatawan karyawan juga meningkat.
\end{abstract}

Kata Kunci: pendidikan, pelatihan, bahasa Inggris, keknik kepemanduan

\section{THE ROLE OF EDUCATION, TRAINING IN ENGLISH, AND THE GUIDING TECHNIQUE ON FISHERIES TOURISM DEVELOPMENT}

\begin{abstract}
The purpose of this research was to describe the role of education, training in English and the guiding technique on improving the ability of CV. Dewata Laut workers in serving tourists who visited this company. This study used the pre-experiment design with education, training in English, and the guiding technique as the treatments. The data were collected by administering a test, conducting observations and interviews and distributing questionnaires. The test was a comprehension test administered before and after the treatments. The data were analyzed through descriptive qualitative and quantitative analyses. The findings showed that (1) the ability of C.V. Dewata Laut workers improved by $53.69 \%$; (2) the ability in guiding also improved by $49.53 \%$; (3) the ability to serve the tourists also improved.
\end{abstract}

Keywords: education, training in English, guiding technique

\section{PENDAHULUAN}

Sebagai salah satu provinsi yang ada di Indonesia, Provinsi Bali sejak lama telah dikenal oleh dunia sebagai salah satu tujuan wisata yang cukup menarik untuk dikunjungi. Sebagai salah satu tujuan wisata yang cukup tersohor di dunia, Provinsi Bali sejak lama telah mengembangkan kepariwisataannya ke arah wisata budaya (cultural tourism) dengan mengandalkan produk-produk seni budaya dan prosesi ritual keagamaan sebagai objek wisata. Terkait dengan itu, para pekerja seni dan budayawan secara terus-menerus diransang untuk berkreasi dan berkarya. Setiap prosesi ritual keagamaan juga dipublikasikan untuk ditonton dan setiap tempat suci juga telah dibuka untuk mendapat kunjungan wisatawan.

Kendatipun telah terbukti bahwa pariwisata budaya yang dikembangkan di Bali mampu meningkatkan kesejahteraan sebagian masyarakat Bali, di balik itu pariwisata Bali yang bercorak budaya ini juga terbukti telah memberikan ekses negatif yang merugikan Bali secara keseluruhan. Beberapa ekses negatif yang dimaksud adalah: (1) adanya komersialisasi produk-produk seni budaya dan prosesi-prosesi ritual keagamaan yang bersifat sakral; (2) adanya pelecehan oleh wisatawan terhadap kesucian tempat-tempat yang disucikan oleh masyarakat Bali, terutama pura dan tempat-tempat suci 
lainnya; dan (3) adanya penularan sikap dan tatanan hidup asing yang tidak sesuai dengan nilai-nilai dan norma yang berlaku dalam masyarakat Bali yang berbasis Hindu. Komersialisasi produk-produk seni budaya yang bersifat sakral yang telah di paparkan di atas telah menimbulkan efek negatif lainnya, yaitu berupa pencurian benda-benda seni budaya yang bersifat sakral yang dapat sangat menyinggung perasaan dan emosi masyarakat Bali yang berbasis Hindu.

Terkait dengan adanya berbagai ekses negatif yang diakibatkan oleh pariwisata Bali yang bercorak budaya, sudah sepantasnya Bali mengembangkan corak wisata lainnya agar wisatawan yang berkunjung ke Bali memunyai pilihan lain sehingga ekses negatif dari wisata budaya dapat dikurangi. Selain bermanfaat untuk mengurangi ekses negatif wisata budaya, pengembangan corak wisata lain juga bermanfaat untuk mengembangkan kepariwisataan Bali secara keseluruhan sehingga kepariwisataan Bali mampu menampung selera wisatawan yang beragam. Beberapa corak wisata lain yang mungkin dikembangkan di Bali adalah wisata alam dan petualangan (adventure tourism), wisata ekologis (ecotourism), wisata kuliner, wisata spiritual dan wisata perikanan (mina wisata).

Terkait dengan wisata perikanan (mina wisata), di Bali terutama di Kabupaten Buleleng merupakan wilayah yang cukup potensial untuk mengembangkan mina wisata. Hal itu disebabkan terdapat banyak sentra produksi perikanan, baik perikanan budidaya maupun perikanan tangkap yang dapat dikemas menjadi objek mina wisata. Beberapa desa di Buleleng yang telah menjadi sentra produksi perikanan adalah Desa Tembok, Desa Les, Desa Kubutambahan, Desa Bungkulan, Desa Sangsit, Desa Anturan, Desa Celukan Bawang, Desa Patas, Desa Gerokgak, Desa Musi, Desa Penyabangan, Desa Gondol, Desa Banyupoh, Desa Pemuteran, Desa Sumberkima, Desa Pejarakan, dan Desa Sumberkelampok. Di desa-desa yang disebutkan di atas, telah berkembang dua sistem produksi perikanan, yaitu sistem perikanan budidaya dan sistem perikanan tangkap.
Terkait dengan sistem perikanan budidaya yang ada di Kabupaten Buleleng, salah satu sentra perikanan budidaya yang sangat cocok dikembangkan menjadi model mina wisata di Kabupaten Buleleng adalah sentra perikanan budidaya yang dikelola oleh CV. Dewata Laut yang berlokasi di Desa Penyabangan, Kecamatan Gerokgak, Kabupaten Buleleng, Bali. Skala usaha CV tersebut cukup besar dengan komoditas perikanan yang cukup beragam. Sentra perikanan budidaya yang dikelola oleh CV tersebut berlokasi di pinggir pantai dengan latar belakang pemandangan (landscap) yang indah dan berdekatan dengan pusat kawasan wisata Pemuteran. Selain itu, sentra perikanan budidaya yang dikelola oleh CV juga sudah sering mendapat kunjungan wisatawan mancanegara.

Banyak faktor yang dapat mendukung upaya pengembangan sentra perikanan budidaya yang dikelola oleh CV. Dewata Laut untuk menjadi model mina wisata, namun ada dua kendala utama yang diduga menghambat upaya tersebut. Kedua kendala utama yang dimaksud adalah (1) rendahnya kemampuan bahasa Inggris para karyawan yang bekerja di CV. Dewata Laut sehingga mereka tidak mampu berkomunikasi dengan wisatawan; dan (2) rendahnya kemampuan teknik kepemanduan para karyawan di CV. Dewata Laut sehingga dapat sehingga mengecewakan para wisatawan. Kedua kendala ini terjadi karena latar belakang pendidikan karyawan CV. Dewata Laut ini masih minim. Sebagian besar para karyawan hanya tamat sekolah dasar, sebagian sempat di sekolah menengah (SMP dan SMA), tetapi tidak tamat, hanya sebagian kecil tamat sekolah menengah (SMP dan SMA). Karyawan CV. Dewata Laut pada umumnya bekerja hanya mengandalkan kemampuan memelihara ikan dan mengelola media budidaya. Kemampuan ini mereka dapatkan bukan dari pendidikan formal, tetapi dari pengalaman belajar langsung di lapangan. Agar sentra perikanan budidaya yang dikelola oleh CV. Dewata Laut dapat berkembang menjadi model mina wisata, kedua kendala itu harus diatasi melalui peningkatan kemampuan para kar- 
yawan dalam hal bahasa Inggris dan teknik kepemanduan.

Terkait dengan upaya peningkatan kemampuan para karyawan CV. Dewata Laut dalam hal bahasa Inggris dan teknik kepemanduan dalam rangka mengembangkan sentra perikanan budidaya menjadi objek mina wisata, ada beberapa permasalahan yang menarik untuk dikaji. Beberapa permasalahan yang dimaksud adalah (1) apakah pendidikan dan pelatihan bahasa Inggris dapat meningkatkan kemampuan para karyawan; dan (2) apakah pendidikan dan pelatihan dalam bidang teknik kepemanduan dapat meningkatkan kemampuan karyawan dalam memandu wisatawan? Jawaban kedua permasalahan tersebut diharapkan dapat mengembangkan mina wisata di Bali, khususnya di Kabupaten Buleleng.

\section{METODE}

Penelitian ini dirancang sebagai penelitian praeksperimenal dengan pola one group pretest post test design. Penelitian ini tidak menggunakan kelompok kontrol sehingga tidak semua variabel yang berpengaruh pada hasil penelitian dapat dikontrol dengan ketat. Penelitian hanya memakai satu kelompok sampel yang semuanya adalah karyawan CV. Dewata Laut yang dipilih dengan teknik purposive sampling berdasarkan tingkat kemampuan berbahasa Inggris dan teknik kepemanduan. Penggunaan teknik purposive dalam pengambilan sampel didasarkan atas pertimbangan karakter populasi yang ada dan karakter sampel yang diperlukan sesuai dengan spesifikasi tujuan penelitian (Zuriah, 2006:141). Karyawan yang dipilih sebagai sampel adalah 20 orang karyawan yang belum sempat mengenyam pendidikan sekolah menengah dengan rentangan umur antara 16 tahun sampai 37 tahun dengan komposisi gender 19 orang pria dan 1 orang wanita. Penelitian ini tidak menggunakan kelompok kontrol (pembanding) karena dengan memberikan pretest dan posttest, maka pengaruh perlakuan dapat diyakini akan tampak dengan sendirinya.

Perlakuan eksperimental yang diberikan berupa pemberian pendidikan dan pelatihan bahasa Inggris dan teknik kepemanduan. Materi pelatihan bahasa Inggris yang diberikan meliputi lima aspek, yaitu perbendaharaan kata (vocabulary), membaca (reading), menulis (writing), mendengarkan (listening), dan berbicara (speaking). Materi teknik kepemanduan yang diberikan meliputi tiga aspek, yaitu teknik komunikasi, teknik pelayanan, dan teknik penguasaan materi objek wisata (PMOW).

Pendidikan dan pelatihan bahasa Inggris dan teknik kepemanduan ini masing-masing berlangsung sebanyak 10 kali pertemuan dengan durasi 120 menit untuk setiap kali pertemuan yang dilakukan selama empat bulan. Pelaksanaan pendidikan dan pelatihan bahasa Inggris dan teknik kepemanduan ini berlangsung sore hari (pukul 18.00 - 20.00) setelah jam kerja para karyawan berakhir. Karena pendidikan dan pelatihan ini berlangsung di lokasi para karyawan bekerja, pola pendidikan dan pelatihan ini dikenal dengan pola on job eduation and training yang disingkat pola ONJET (Usman, 2012:61).

Di samping mengikuti pola ONJET, pelatihan merupakan pelatihan yang berbasis kinerja, yaitu pelatihan yang menitikberatkan praktik langsung (Sutisna dan Trisnamasyah, 2010:377). Teknik itu sengaja dipilih karena pelatihan semacam ini sangat mudah dilaksanakan dan telah terbukti mampu dengan cepat meningkatkan keterampilan para peserta pelatihan.

Model pendidikan dan pelatihan yang diterapkan adalah model pendidikan dan pelatihan yang dianjurkan oleh Noe (Usman, 2012: 157) yang terdiri atas empat tahap, yaitu analysis, design, development, dan implementation. Narasumber dan instruktur yang dilibatkan dalam pendidikan dan pelatihan ini adalah staf dosen Jurusan D3 Bahasa Inggris Kepariwisataan, Fakultas Bahasa dan Seni, Universitas Pendidikan Ganesha. Sebelum diberi perlakuan, para pekerja yang menjadi peserta terlebih dahulu diberi pretes untuk mengetahui kemampuan awal mereka dalam hal bahasa Inggris dan teknik kepemanduan. Tes yang diberikan berupa tes pemahaman konsep dan tes keterampilan. Setelah itu, kegiatan pendidikan dan pelatihan dimulai. 
Metode pelatihan yang digunakan adalah ceramah, diskusi, demonstrasi, dan latihan. Digunakannya metode demonstrasi dalam pendidikan dan pelatihan ini didasari oleh hasil penelitian Rohaeti, dkk. (2014:3) yang mengemukakan bahwa metode demonstrasi cocok digunakan untuk memberikan keterampilan proses kepada peserta didik dan dapat memberikan pengalaman belajar yang lebih kongkret. Setelah kegiatan pendidikan dan pelatihan berakhir, kemudian dilakukan posttest untuk mengetahui ada tidaknya peningkatan kemampuan hal bahasa Inggris dan teknik kepemanduan.

Selain menggunakan metode tes, pengumpulan data juga dilakukan dengan observasi, wawancara, dan kuesioner. Hal-hal yang diobservasi dalam penelitian ini adalah aktivitas peserta dan instruktur dalam kegiatan pendidikan dan pelatihan serta proses layanan yang diberikan oleh peserta kepada wisatawan yang berkunjung. Pihak yang dijadikan responden dalam wawancara dan kuesioner adalah peserta pendidikan dan pelatihan dan sejumlah wisatawan yang mendapatkan pelayanan dari para peserta.

Analisis data dilakaukan dengan teknik deskriptif kuantitatif dan deskriptif kualitatif. Data yang dianalisis dengan teknik deskriptif kuantitatif adalah data kemampuan berbahasa Inggris dan teknik kepemanduan para peserta pendidikan dan pelatihan. Data pretest dan posttes diolah untuk didapatkan angka rata-rata persentase peningkatan kemampuan berbahasa Inggris dan teknik kepemanduan para peserta. Data yang diolah dengan teknik deskriptif kualitatif adalah data tentang tingkat kepuasan para wisatawan dalam menerima layanan para karyawan CV. Dewata Laut yang telah mendapat pendidikan dan pelatihan.

\section{HASIL DAN PEMBAHASAN}

Pertama, setelah mengikuti kegiatan pendidikan dan pelatihan, kemampuan bahasa Inggris karyawan CV. Dewata Laut meningkat rata-rata sebanyak 53,69 persen. Angka peningkatan ini terungkap dari hasil tes yang dilakukan setelah kegiatan pembelajaran (posttest) dan kemudian dibandingkan dengan hasil tes sebelum kegiatan pembelajaran (pretes). Peningkatan kemampuan ini tampak signifikan dalam lima aspek yang diajarkan, yaitu yang mencakup perbendaharaan kata, membaca, menulis, menyimak, dan berbicara. Besarnya persentase peningkatan kemampuan berbahasa Inggris tersebut dapat dilihat pada Tabel 1 .

\section{Tabel 1. Data Persentase Peningkatan Ke- mampuan Berbahasa Inggris}

\begin{tabular}{lc}
\hline Aspek Bahasa Inggris & Peningkatan $(\%)$ \\
\hline Perbendaharaan (Vocab) & 58,65 \\
Membaca (Reading) & 45,20 \\
Menulis (Writing) & 51,45 \\
Mendengar (Listening) & 54,15 \\
Berbicara (Speaking) & 59,00 \\
\hline Jumlah & 268,45 \\
\hline Rata-rata & 53,69 \\
\hline
\end{tabular}

Secara grafis, besarnya persentase peningkatan kemampuan berbahasa Inggris para peserta pelatihan dapat ditunjukkan melalui digram batang pada Gambar 1 .

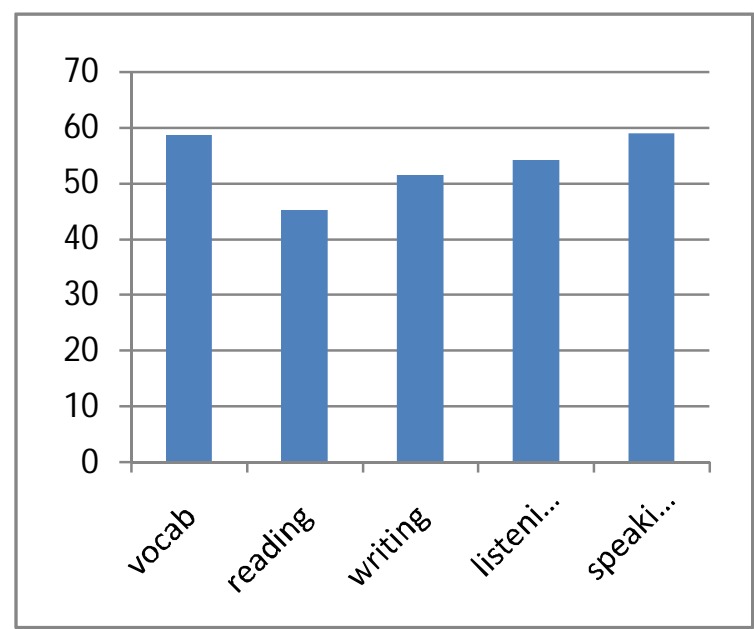

\section{Gambar 1. Grafik Kemampuan Bahasa Inggris Karyawan CV. Dewata Laut}

Dengan meningkatnya kemampuan bahasa Inggris, karyawan menyatakan lebih berani dan lebih percaya diri dalam melayani kedatangan wisatawan yang berkunjung. Hal ini terungkap dari hasil wawancara dan hasil kuesioner yang menempatkan para karyawan (peserta 
pelatihan) sebagai responden. Melalui observasi terungkap bahwa para karyawan ini tampak sudah bisa menjelaskan nama ikan, nama sarana yang digunakan dalam pemeliharaan ikan, cara memelihara dan cara memanen dan mengolah hasil panen ikan dengan menggunakan bahasa Inggris walaupun masih canggung, malu, dan terkadang salah.

Kedua, setelah mengikuti kegiatan pendidikan dan pelatihan dalam bidang teknik kepemanduan, kemampuan teknik kepemanduan para karyawan CV. Dewata Laut yang menjadi peserta pelatihan meningkat rata-rata sebanyak 49,53 persen. Peningkatan kemampuan ini tampak signifikan pada tiga aspek yang diajarkan, yaitu teknik komunikasi, teknik pelayanan, dan penguasaan materi objek wisata (PMOW). Data peningkatan kemampuan memanduan dapat dilihat pada Tabel 2.

\section{Tebel 2. Data Persentase Peningkatan Ke-} mampuan Teknik Kepemanduan

\begin{tabular}{lc}
\hline Aspek Kepemanduan & Peningkatan $(\%)$ \\
\hline Teknik komunikasi & 49,14 \\
Teknik pelayanan & 42,19 \\
PMOW & 57,26 \\
\hline Jumlah & 148,59 \\
\hline Rata-rata & 49,53 \\
\hline
\end{tabular}

Secara grafis, persentase peningkatan kemampuan memandu ini dapat dilihat pada Gambar 2.

Dengan merekapitulasi paparan data di atas, tampak bahwa karyawan CV. Dewata Laut mengalami rata-rata persentase peningkatan kemampuan bahasa Inggris sebesar 53,69\%, dan rata-rata persentase peningkatan kemampuan teknik kepemanduan sebesar 49,53\%. Untuk lebih jelasnya, berikut disajikan grafik untuk menunjukkan peningkatan kemampuan tersebut (Gambar 3).

Ketiga, setelah para karyawan CV. Dewata Laut mendapat pendidikan dan pelatihan dalam bidang bahasa Inggris dan teknik kepemanduan, terdapat peningkatan mutu pelayanan para karyawan kepada wisatawan yang berkunjung ke CV. Dewata Laut. Hal ini ter- ungkap dari hasil observasi terhadap aktivitas pelayanan yang dilakukan oleh para karyawan kepada para wisatawan, dan dari hasil wawancara kepada sejumlah wisatawan yang mendapat pelayanan dari para karyawan. Beberapa wisatawan yang diwawancarai menyatakan cukup puas terhadap pelayanan yang diberikan.

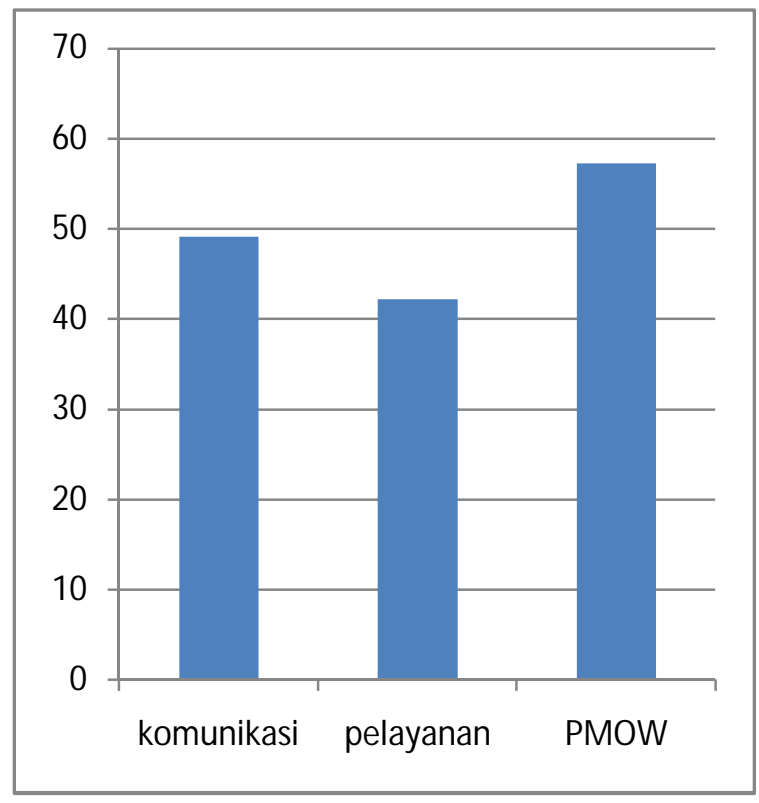

Gambar 2. Grafik Kemampuan Teknik Kepemanduan Karyawan CV. Dewata Laut

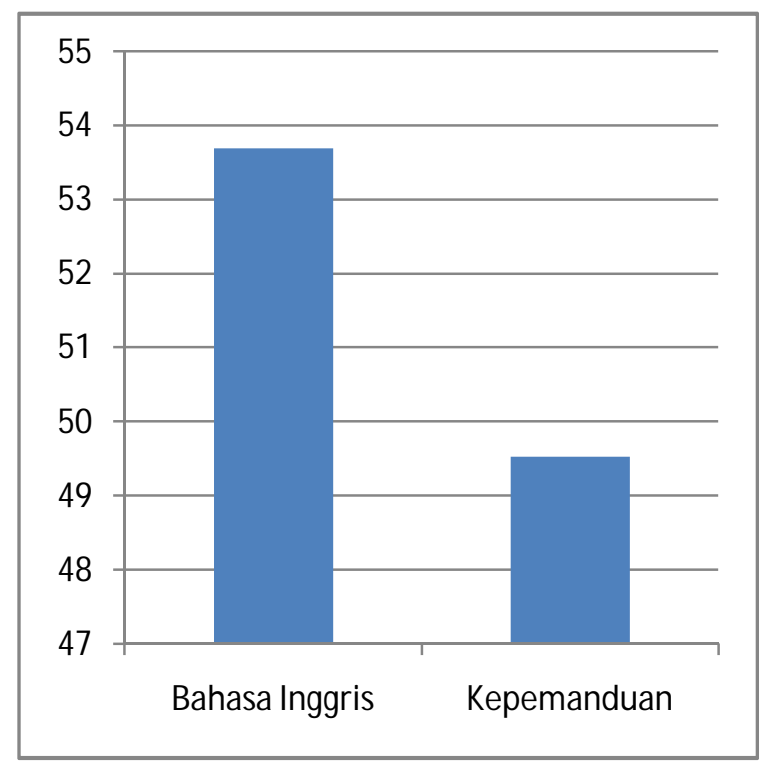

Gambar 3. Grafik Rata-rata Persentase Peningkatan Kemampuan Bahasa Inggris dan Teknik Kepemanduan Karyawan CV. Dewata Laut 
Terkait dengan adanya peningkatan kemampuan karyawan berbahasa Inggris, hal ini merupakan konsekuensi logis dari keikutsertaannya dalam kegiatan pendidikan dan pelatihan bahasa Inggris yang berlangsung selama $10 \mathrm{kali}$ pertemuan, atau setara dengan 1.200 menit. Peningkatan kemampuan karyawan berbahasa Inggris ini merupakan dampak positif dari proses pembelajaran yang berlangsung secara kondusif di bawah bimbingan narasumber dan instruktur yang cukup mumpuni dalam bidang bahasa Inggris.

Dalam hal ini, narasumber dan instruktur berhasil secara tepat menerapkan metode ceramah dan latihan dalam proses pembelajaran dengan menyampaikan materi secara bertahap, mulai dari materi dasar hingga materi yang lebih lanjut sesuai dengan tingkat pemahaman awal para peserta yang diketahui dari hasil pre test. Metode ceramah yang diterapkan oleh narasumber dapat membuat para karyawan paham tentang tata bahasa (grammar) dan kaya dengan perbendaharaan kata (vocabulary). Metode latihan yang dilakukan dapat membuat para karyawan meningkat kemampuannya dalam hal bicara (speaking), menulis (writing), membaca (reading), dan mendengar (listening). Di samping karena faktor strategi dan metode pembelajaran, keberhasilan para narasumber dan instruktur dalam meningkatkan kemampuan para karyawan dalam hal bahasa Inggris adalah juga merupakan dampak positif dari modul yang disiapkan oleh narasumber. Modul yang dibuat oleh narasumber bahasanya cukup jelas, sistematis, materinya sangat kontekstual dalam dunia perikanan, dan dilengkapi dengan gambar-gambar yang cukup menarik para peserta pelatihan. Dalam dunia pendidikan sudah terbukti bahwa modul yang disusun dengan baik dengan bahasa yang cukup jelas sangat memudahkan pebelajar (siswa) dalam memahami materi yang diajarkan.

Peningkatan kemampuan karyawan dalam teknik kepemanduan merupakan konsekuensi logis dari keikutsertaan mereka pada kegiatan pendidikan dan pelatihan teknik kepemanduan yang berlangsung selama $10 \mathrm{kali}$ pertemuan, atau setara dengan 1.200 menit.
Peningkatan kemampuan karyawan dalam teknik kepemanduan merupakan dampak positif dari proses pembelajaran dan pelatihan yang berlangsung secara kondusif di bawah bimbingan narasumber dan instruktur yang cukup mumpuni dalam bidang teknik kepemanduan. Dalam hal ini para narasumber dan instruktur secara tepat menerapkan pendekatan dan metode ceramah, demonstrasi dan latihan (praktik) langsung dengan mengetengahkan materi kepamanduan yang kontekstual dalam bidang perikanan.

Materi teknik kepemanduan yang disampaikan oleh narasumber melalui ceramah telah menambah pengetahuan dan wawasan para karyawan dalam hal teknik kepemanduan. Teknik memandu wisatawan yang dicontohkan oleh instruktur di hadapan para karyawan telah membuat para karyawan semakin paham tentang teknik kepemanduan. Kesempatan berlatih memandu wisatawan yang diberikan oleh instruktur kepada para karyawan membuat para karyawan dapat mempraktikkan secara langsung tentang teknik memandu wisatawan sehingga keterampilannya menjadi meningkat.

Peranan profesionalisme narasumber dan instruktur untuk meningkatkan kemampuan karyawan CV. Dewata Laut berberbahasa Inggris dan teknik kepemanduan sesuai dengan hasil penelitian Widoyoko dan Rinawati (2012: 279) yang mengungkapkan bahwa guru (narasumber dan instruktur) yang kinerjanya baik (profesional), dapat menumbuhkan motivasi belajar pada peserta didik. Dengan demikian, guru (narasumber dan instruktur) merupakan faktor utama dalam proses pendidikan, melebihi peranan faktor lainnya seperti sarana dan parsarana pendidikan.

Di samping karena faktor kemampuan narasumber, instruktur, metode, dan faktor modul, peningkatan kemampuan karyawan dalam berbahasa Inggris dan teknik kepemanduan juga merupakan pengaruh faktor motivasi internal yang cukup tinggi dari para karyawan. Peranan motivasi internal ini sudah sesuai dengan hakikat dari motivasi yang merupakan kekuatan (energi) yang mampu mendorong seseorang untuk melakukan atau tidak melakukan sesuatu 
aktivitas. Dorongan untuk melakukan atau tidak melakukan suatu kegiatan didasari oleh adanya kebutuhan untuk melakukan atau tidak melakukan kegiatan tersebut (Widoyoko dan Rinawati, 2012:279).

Motivasi belajar pada siswa merupakan hal yang sangat penting agar guru dapat melakukan proses pembelajaran secara efektif di dalam kelas (Sawrey dan Telford, 1971:441). Hal ini terungkap dalam wawancara dan hasil kuesioner yang diisi oleh para karyawan. Mereka menyatakan sangat tertarik untuk belajar bahasa Inggris dan teknik kepemanduan karena sebagai masyarakat yang bermukim di dekat kawasan wisata, dalam kesehariannya sering bertemu dan berhubungan dengan wisatawan asing. Bahkan, terungkap juga bahwa sebelum bekerja di CV. Dewata Laut, beberapa dari mereka pernah bercita-cita menjadi pemandu wisata dan bekerja di hotel. Namun, karena faktor pendidikan yang kurang memadai, mereka ditolak, dan akhirnya bekerja di CV. Dewata Laut. Sebagai informasi perlu disampaikan bahwa CV. Dewata Laut dan tempat bermukim karyawan lokasinya berdampingan dengan kawasan wisata Batu Ampar yang meliputi wilayah Banyupoh, Pemuteran, Sumberkima, Goris, dan Pejarakan.

Peningkatan mutu pelayanan karyawan kepada para wisatawan yang berkunjung ke CV. Dewata Laut merupakan konsekuensi logis dari peningkatan kemampuan mereka dalam berbahasa Inggris dan teknik kepemanduan yang diperoleh melalui kegiatan pendidikan dan pelatihan. Peningkatan mutu pelayanan para karyawan kepada para wisatawan merupakan hal yang sudah sesuai dengan hakikat pelatihan yang berorientasi hasil (PBH). Menurut Robinson dan Robinson (Sutarto, 2013:185), pelatihan berorientasi hasil ( $\mathrm{PBH})$ adalah pelatihan yang ditujukan untuk menghasilkan tenaga terampil sesuai dengan tuntutan pekerjaan. Hal ini sesuai dengan teori Human Capital Invesment yang dikemukakan oleh Becker (Sutarto, 2013:185).

Peningkatan kemampuan karyawan dalam berbahasa Inggris dan teknik kepemanduan membuat mereka menjadi lebih percaya diri dan lebih terampil dalam melayani wisatawan. Selain itu, juga dipengaruhi oleh adanya buku panduan yang disiapkan oleh tim khusus yang dibiayai oleh CV. Dewata Laut.

Buku panduan tersebut berisi seluk-beluk tentang keberadaan CV. Dewata Laut dan penjelasan berbagai jenis ikan yang dibudidayakan yang disusun dalam bahasa Inggris dan dilengkapi dengan gambar berwarna. Buku ini dipegang oleh para karyawan agar mereka dapat menjelaskan dengan baik kepada wistawan. Selain itu, pelayanan yang baik juga akibat peningkatan mutu sarana dan prasarana yang berkaitan dengan pelayanan wisatawan, seperti ruang pertunjukkan (show room), toilet, tempat parker, dan mini bar.

Dipandang dari segi teoretik, peranan proses pendidikan dan pelatihan dalam meningkatkan kemampuan karyawan untuk berbahasa Inggris dan teknik kepemanduan sangat sesuai dengan teori yang ada. Notoatmodjo (1992:27) menyatakan bahwa pendidikan merupakan suatu proses pengembangan kemampuan manusia ke arah yang diinginkan, sedangkan pelatihan merupakan bagian dari suatu proses pendidikan yang bertujuan untuk meningkatkan kemampuan atau keterampilan khusus seseorang atau sekelompok orang. Simanjutak (1985:58) menyatakan bahwa pendidikan memberikan pengetahuan kepada seseorang bukan hanya pengetahuan yang terkait langsung dengan pekerjaan, tetapi juga pengetahuan yang menjadi landasan untuk mengembangkan dirinya. Sementara itu, Dale Yoder (Moekidjat, 1991:2) menyatakan bahwa pelatihan merupakan pengembangan tenaga kerja untuk pekerjaan-pekerjaan tertentu. Edwin Flippo (Moekidjat, 1991:6) menyatakan bahwa pelatihan adalah tindakan untuk meningkatkan pengetahuan dan kecakapan seseorang untuk melaksanakan suatu pekerjaan tertentu. Pendidikan dan pelatihan merupakan upaya untuk mengembangkan sumberdaya manusia, terutama untuk pengembangan aspek kemampuan intelektual, keterampilan, dan kepribadian manusia (Notoatmodjo, 1992:27). Simanjuntak (1985:58) juga menyatakan bahwa pendidikan dan pelatihan tidak saja menambah pengetahuan, tetapi juga 
meningkatkan keterampilan kerja sehingga dapat meningkatkan produktivitas kerja. Moekidjat (1991:4 ) menyatakan bahwa pendidikan dan latihan merupakan upaya untuk membantu seseorang untuk meningkatkan efektivitas dan produktivitas kerja.

\section{PENUTUP}

Beberapa hal yang dapat disimpulkan dari hasil penelitian ini sebagai berikut. Pertama, pendidikan dan pelatihan bahasa Inggris dapat meningkatkan kemampuan karyawan CV. Dewata Laut. Hal ini merupakan pengaruh dari beberapa faktor, yaitu kemampuan narasumber dan instruktur cukup baik dalam penguasaan materi dan penerapan metode pembelajaran; tersedianya modul pembelajaran yang memudahkan para karyawan untuk belajar bahasa Inggris; adanya motivasi internal yang cukup kuat dari karyawan CV. Dewata Laut untuk bisa berbahasa Inggris. Kedua, pendidikan dan pelatihan teknik kepemanduan dapat meningkatkan kemampuan karyawan CV. Dewata Laut dalam hal teknik kepemanduan. Hal ini merupakan pengaruh dari beberapa faktor, yaitu penguasaan narasumber dan instruktur dalam hal materi teknik kepemanduan cukup baik, para narasumber dan instruktur dapat memilih dan menerapkan metode pembelajaran dan pelatihan (ceramah, demonstrasi, dan latihan) secara baik dan tepat, adanya modul teknik kepemanduan yang mudah dipelajari oleh para karyawan, adanya motivasi internal yang cukup kuat dari para karyawan untuk mengetahui teknik memandu wisatawan yang baik.

Ketiga, pendidikan dan pelatihan bahasa Inggris dan teknik kepemanduan dapat meningkatkan mutu pelayanan karyawan kepada wisatawan yang berkunjung ke CV. Dewata Laut. Hal ini merupakan pengaruh dari beberapa faktor, yaitu adanya peningkatan kemampuan para karyawan dalam berbahasa Inggris dan teknik kepemanduan sehingga dapat menambah rasa percaya diri dan keterampilan para karyawan dalam melayani wisatawan, adanya buku panduan yang berisi materi tentang seluk beluk keberadaan CV. Dewata Laut dan penjelasan tentang berbagai jenis ikan yang dibudi- dayakan yang sangat membantu para karyawan dalam memandu wisatawan yang berkunjung, adanya peningkatan mutu sarana dan prasarana yang berkaitan dengan pelayanan wisatawan seperti ruang pertunjukkan (show room), toilet, tempat parkir dan adanya mini bar.

\section{UCAPAN TERIMA KASIH}

Ucapan terima kasih disampikan kepada beberapa pihak, yaitu : (1) pemilik CV. Dewata Laut yang telah memberikan izin dan fasilitas untuk melakukan penelitian di CV Dewata Laut; (2) karyawan CV. Dewata Laut yang telah bersedia menjadi subjek penelitian; (3) narasumber dan instruktur yang telah membantu demi kelancaran penelitian ini; (4) pihak DP2M Dikti yang telah memberikan kepercayaan kepada penulis untuk mengerjakan penelitian ini; (5) pengelola Jurnal Cakrawala Pendidikan.

\section{DAFTAR PUSTAKA}

Moekijat. 1991. Latihan dan Pengembangan Sumberdaya Manusia. Bandung: C.V. Mandar Maju.

Notoatmodjo, S. 1992 Pengembangan Sumberdaya Manusia. Jakarta: Rineka Cipta.

Rohaeti, Salimi, Sugiyono. 2014. "Peningkatan Hasil Belajar Siswa dengan Menggunakan Metode Demonstrasi pada Pembelajaran IPS. Jurnal Pendidikan dan Pembelajaran, III (4), halaman 1 - 12.

Sawrey dan Telford. 1971. Educational Psychology (Fourth Edition). Boston: Allyn And Bacon.

Simanjuntak, P. 1985. Pengantar Ekonomi Sumberdaya Manusia. Jakarta: Lembaga Penerbit Fakultas Ekonomi Universitas Indonesia.

Sutarto, 2013. "Strategi Pergeseran Paradigma Pelatihan dari Orientasi Aktivitas di Kelas ke Hasil di Tempat Kerja". Cakrawala Pendidikan. XXXII (2), halaman 183 - 195. 
Sutisna dan Trisnamasyah. 2010. "Model Pelatihan Berbasis Kinerja dalam Peningkatan Kompetensi Tutor Pendidikan Kesetaraan". Cakrawala Pendidikan. XXIX (3), halaman 365-378.

Usman, Prasaja, Sunarta. 2012. "Model Diklat Kewirausahaan bagi Remaja Putus Sekolah". Cakrawala Pendidikan. XXXI (1), halaman 55-66.
Widoyoko dan Rinawati. 2012. "Pengaruh Kinerja Guru terhadap Motivasi Belajar Siswa". Cakrawala Pendidikan, XXXI (2), halaman $278-289$.

Zuriah. 2006. Metodologi Penelitian Sosial dan Pendidikan. Jakarta: Bumi Aksara. 